\title{
ISOTOPE KILOWATT PROGRAM QUARTERLY PROGRESS REPORT FOR PERIOD ENDING MARCH 31, 1973
}

23,407

\section{OAK RIDGE NATIONAL LABORATORY}

\author{
OPERATED BY UNION CARBIDE CORPORATION - FUR THE U.S. ATOMIC ENERGY COMMISSION
}




\section{DISCLAIMER}

This report was prepared as an account of work sponsored by an agency of the United States Government. Neither the United States Government nor any agency Thereof, nor any of their employees, makes any warranty, express or implied, or assumes any legal liability or responsibility for the accuracy, completeness, or usefulness of any information, apparatus, product, or process disclosed, or represents that its use would not infringe privately owned rights. Reference herein to any specific commercial product, process, or service by trade name, trademark, manufacturer, or otherwise does not necessarily constitute or imply its endorsement, recommendation, or favoring by the United States Government or any agency thereof. The views and opinions of authors expressed herein do not necessarily state or reflect those of the United States Government or any agency thereof. 


\section{DISCLAIMER}

Portions of this document may be illegible in electronic image products. Images are produced from the best available original document. 
This report was prepared as an account of work sponsored by the United States Government. Neither the United States nor the United States Atomic Energy Commission, nor any of their employees, nor any of their contractors, subcontractors, or their employees, makes any warranty, express or implied, or assumes any legal liability or responsibility for the accuracy, completeness or usefulness of any information, apparatus, product or process disclosed, or represents that its use would not infringe privately owned rights. 
Contract No. W-7405-eng-26

Reactor Division

ISOTOPE KILOWATT PROGRAM QUARTERLY PROGRESS REPORT FOR PERIOD EINDING MARCH 31, 1973

A. P. Fraas, Program Director

G. Samuels, Associate Director

NOTICE

This report was prepared as an account of work sponsored by the United States Government. Neither the United States nor the United States Atomic Energy Commission, nor any of their employees, nor any of their contractors, subcontractors, or their employees, makes any warranty, express or implied, or assumes any legal liability or responsibility for the accuracy, completeness or usefulness of any information, apparatus, pletess or usefuls disclosed, or represents that its use would not infringe privately owned rights.

NOTICE This document contains information of a preliminary nature and was prepared primarily for internal use at the Oak Ridge National Laboratory. It is subject to revision or correction and therefore does not represent a final report.

OAK RIDGE NATIONAL IABORATORY

Oak Ridge, Tennessee 37830 operated by

UNION CARBIDE CORPORATION

for the

U.S. ATOMIC ENERGY COMMISSION 
Blank Page 
FOREWORD

In 1968 the Oak Ridge National Laboratory started work on a program to evaluate various types of radioisotope energy conversion systems for the production of 1 to $10 \mathrm{~kW}$ of electric power for terrestrial and undersea applications. This program is being carried out for the U. S. Atomic Energy Commission Division of Reactor Development and Technology and the Naval Facilities Engineering Command. The first phase of the program was a parametric and engineering analysis comparing the principal isotope fuels and the principal types of energy conversion system that ha ve been proposed for applications of this sort, and the preparation of a set of conceptual designs for the more attractive systems. That work was completed in the summer of 1969 and was reported in Ref. 1. In October of 1969 ORNL was asked to proceed with a detailed engineering study of the three most promising systems selected from those covered in Phase I of the program. These three systems now under study are a 2-kW(e) thermoelectric system, a 3-kW(e) steam Rankine cycle system, and a 5-kW(e) organic Rankine cycle system.

The first step in the effort was to evolve a program plan for a threeyear effort to be carried out in calendar years 1970, 1971, and 1972. The conceptual designs presented in Task I were reexamined and possible improvements were considered with particular attention to the difficult development problems. A variety of engineering tests was considered as a means of evaluating the technology, solving the principal technical problems, and investigating engineering uncertainties that should be resolved before settling on the design of a prototype power plant. In view of the limited funds and the desirability of narrowing the field to a single Rankine cycle system, particular attention was given to the relative merits of the steam and organic Rankine cycle systems.

The first quarter of 1970 was devoted to firming up reference designs for the three types of system, selecting the most crucial experiments required to evaluate the technology, and settling on a program plan for the three-year effort. ${ }^{2}$ With this first quarter's work as a foundation, the second quarter was then devoted to firming up the details of the reference designs, firming up details of the experiments to be conducted, and preparation of topical reports covering the three reference designs with their 
associated experiments. ${ }^{3}$ The subsequent quarters have been devoted to the design and construction of the most urgent experiments.4-13 The objective is to establish as well as possible by June 1973 the design bases for prototype isotope power plants with a clear delineation of the development program required in each case including firm estimates of the cost and time for the various programmatic steps.

This is the thirteenth in a series of quarterly progress reports. Topical reports present the work carried out in particular areas when key tasks are completed. When a topical report is issued essentially concurrently with a quarterly report, to avoid duplication only a very brief summary of its contents is included in the quarterly. 
CONTENTS

$\underline{\text { Page }}$

1.0 SUMMARY . . . . . . . . . . . . . . . . 1

2.0 ORGANIC FLUID EVALUATION . . . . . . . . . . 2

Organic Fluid Capsule Decomposition Test . . . . . 2

Organic Fluid Decomposition Test Facility ....... 3

3.0 THERMOELECTRIC SYSTEM . . . . . . . . . . . 5

4.0 THERMAL FUSE AND INSULATION . . . . . . . . . . 5

5.0 FULL-SCALE FUSIBLE INSULATION EVALUATION TEST . . . . . 6

6.0 FUEL CAPSULE TESTS . . . . . . . . . . . . . 6

REFERENCES . . . . . . . . . . . . . . . 19 


\section{ISOTOPE KILOWATT PROGRAM QUARTERLY PROGRESS REPORT FOR PERIOD ENDING MARCH 31, 1973}

\subsection{SUMMARY}

The last of the capsules used in the organic fluid capsule decomposition test have been examined, the results have been compiled, and a final report on the tests is being prepared. The data indicate that the amount of gas evolved from the fluid shows no statistically significant change with an increase in the radiation dose rate up to $800,000 \mathrm{rad}$ in $14,000 \mathrm{hr}$, nor was there any significant increase in the amount of gas evolved in going from 1,000 hr to 14,000 hr at any of the test conditions. The data also indicate that the gas volume evolved in the capsules loaded with Dowtherm A supplied by Dow Chemical Company was much higher than was the case for the capsules which contain material produced by the Eastman Kodak Company •

Tests with the 1/4-scale organic loop decomposition test facility were terminated during the quarter because the program was being terminated. Throughout the tests the rate of gas evolution from the organic fluid was much greater than in the capsule tests. At least part of the difficulty appears to have come from the pumps. Disassembly of the pump that gave the greater amount of trouble indicated that it had never been properly repaired at the vendor after it failed in the course of the acceptance test.

Tests of the heat pipes for the full-scale heat block test were completed and all of the heat pipes were found to operate satisfactorily in both the vertical and horizontal positions.

The topical report covering the thermal fuse and insulation development test work was completed and copies of the draft were submitted to the AEC and NAVFAC for review.

The new components for the full-scale fusible insulation evaluation test were completed and installed in the heat block-shield assembly during the quarter. The test program was initiated but it was found that the operating temperature of the heat pipes was only $930^{\circ} \mathrm{F}$ rather than the expected $1050^{\circ} \mathrm{F}$. The lower temperature is believed to have stemmed from a higher heat loss rate than expected in the condenser region of the heat 
pipes. This seems to have been caused by eccentricity between the heat pipe and the water-cooled sleeve in the condenser region which increased the thermal conductance. The length of the water coils is being reduced by about $17 \%$ to compensate for this effect.

The two completed fuel capsules were preconditioned at $1600^{\circ} \mathrm{F}$ for one hour in argon and dimensionally inspected. Capsule No. 1 was shipped to the Naval Ship Research and Development Center, Bethesda, Maryland, for hydrostatic testing. Capsule No. 2 was submitted to a program of thermal shock, free drop, and percussion tests. Prior to each test and following each test the capsule was leak tested, dimensionally inspected, and photographed. No changes in the capsule resulting from the thermal shock tests or the percussion tests were detected. However, the free-drop test on the plasma arc-welded top end resulted in a deformation of $0.115 \mathrm{in}$. in the threaded area of the wall, and on one side the end was deformed $7 / 32$ in. from a plane perpendicular to the axis of the capsule. A hair-line crack approximately 2 in. long was detected in the cap weld. A gross leak through the crack was indicated upon leak testing. The free-drop test on the electron beam-welded bottom end resulted in a bulge of 0.050 in. in the capsule wall near the inner end of the cap, and on one side the end was deflected 7/16 in. from a plane perpendicular to the capsule axis. The capsule showed no leakage resulting from the bottom end free-drop test.

\subsection{ORGANIC FLUID EVALUATION}

\section{Organic Fluid Capsule Decomposition Test}

Analysis of the remaining capsules was completed and a comparison of the results undertaken. Although preliminary results from the first few capsules indicated that the fraction of hydrogen found in the gas phase of the samples tends to decrease with an increase in the radiation dose rate, detailed analysis of the complete set of data showed no statistically significant difference in either the plain glass capsules or the glass capsules containing stainless wires. Further, the amount of gas evolved did not increase significantly in going from $7,000 \mathrm{hr}$ to $14,000 \mathrm{hr}$. The maximum radiation dose to any capsule was about $800,000 \mathrm{rad}$. The data also indicate that the total gas volume found in the four capsules loaded with the "Dowtherm A" 
material supplied by Dow Chemical Company is much higher than those containing material produced by the Eastman Kodak Company. A comprehensive topical report covering the tests is being prepared.

Organic Fluid Decomposition Test Facility

The facility was operated on natural convection from December 19, 1972 to January 4, 1973. During this time the condenser pressure continued to rise and at the end of $382 \mathrm{hr}$ of operation showed a pressure rise of 0.033 psia. This was an increase of approximately $8.6 \times 10^{-5} \mathrm{psi} / \mathrm{hr}$ with the boiler operating at $350^{\circ} \mathrm{F}$ and the condenser between 90 and $100^{\circ} \mathrm{F}$. Using this rate of rise, the predicted rise for a year's operation would be approximately $0.75 \mathrm{psia}$ or over 7 times that initially anticipated for $600^{\circ} \mathrm{F}$ operation. The boiler was then isolated from the remainder of the system and a test conducted to determine if the pressure rise in the condenser was due to a leak in the system. At the end of an 8 day period with the facility at subatmospheric conditions, there was no evidence of a change in the pressure.

The boiler temperature was then increased and three short term tests of 5 to $7 \mathrm{hr}$ each were run to check the rate of rise when the boiler was operated between $400^{\circ} \mathrm{F}$ and $410^{\circ} \mathrm{F}$. The pump was used to return the condensate to the boiler during these tests. An average of the data for these tests showed the rate of rise in the condenser to have increased to approximatley $3.6 \times 10^{-3} \mathrm{psi} / \mathrm{hr}$.

Tests were terminated during February. A gas phase sample taken at the end of the program again showed the hydrogen concentration to be approximately $60 \%$ by volume. Liquid samples were also taken and the initial analysis of one sample showed no appreciable change in the material. The total impurity level was approximately $80 \mathrm{ppm}$ and consisted of $60 \mathrm{ppm}$ of benzene, $12 \mathrm{ppm}$ of m-methylbiphenyl and 8 ppm p-methylbiphenyl.

During the disassembly of the test facility, the Liquid Dynamics pump which failed was disassembled and inspected. Prior to removing the containment can, Dowtherm A trapped in the suction and discharge lines below the level of the discharge line check valve was drained from the pump and three samples taken for analysis. The liquid when removed from the pump was very black. However, after standing in the sample bottles for several hours, a 
heavy black precipitate was observed in the lower quarter of the bottle and the liquid appeared to be almost colorless.

Analysis of the samples showed that the black residue left after the liquid was removed was carbon. Analysis of the liquid phase of the three samples showed the major contaminant to be benzene. The amount found in the three samples was 980, 995, and 1005 ppm respectively for an average of $993 \mathrm{ppm}$. This high concentration of benzene in the pump indicates that the liquid in the pump bearings had definitely been overheated and the Dowtherm A decomposed.

The seal weld joining the containment housing to the pump casing was then machined off to allow inspection of the rotary parts of the pump. Jack bolts were used to separate the parts and, when separation occurred, the pump impeller and rotor assembly was found to be frozen in the containment can. The clearance between the rear of the pump impeller and the face of the containment can was also found to be less than 5/16 in. Examination of the thrust washer showed no visible wear on either face and indicated the impeller had not been seated against the front shaft support. Further investigation after the impeller and rotor assembly were removed from the containment can showed the following:

1. The rotor had been touching the containment can in at least three places.

2. The face of the inner thrust bearing had worn off and only a thin shell was stuck to the back of the rotor assembly.

3. After the inner thrust bearing failure, the entire assembly (rotor assembly, impeller, bearings, and shaft) moved toward the rear of the containment can.

4. The rear graphitar bearing had been worn off until it was flush with the back of the rotor assembly.

Based on these findings and the short period of operation of this pump before failure occurred, it appears that the pump was never properly repaired after it was damaged during tests by the vendor.

Disassembly and inspection of the test facility were completed during the quarter. A topical report covering the design, construction, and test work is being prepared. 


\subsection{THERMOETECTRIC SYSTEM}

Three heat pipes for the full-scale fusible insulation evaluation test were subjected to performance tests in a heat block designed for operation with a single heat pipe. Some trouble was encountered when withdrawing one of the heat pipes from the heat block in the initial installation. The system was partially disassembled and the hole in the heat block was reamed and honed to an internal diameter of $1.008 \mathrm{in}$. One of the heat pipes was found to be slightly bent and was straightened without difficulty. The system was reassembled and operated without further difficulty.

The first of the three heat pipes to be tested was found to operate satisfactorily except that when operated in a vertical position the temperature in the evaporator region fluctuated $50^{\circ} \mathrm{F}$ with a period of about $15 \mathrm{~min}$. This fluctuation completely disappeared when the heat pipe was tipped to a nearly horizontal position. There was no significant variation in the temperature of the potassium vapor in the condenser section of the heat pipe.

As was the case with the first heat pipe, the temperature in the evaporator region of the second heat pipe fluctuated about $50^{\circ} \mathrm{F}$ with a period of about 15 minutes. This fluctuation completely disappeared when the heat pipe was tipped to a nearly horizontal position. There was no significant temperature variation in the temperature of the potassium vapor in the condenser region.

The third heat pipe tested did not exhibit any temperature fluctuation in the evaporator region during vertical operation. No reason for this variation in performance from one heat pipe to another has been determined.

\subsection{THERMAL FUSE AND INSULATION}

The topical report on the thermal fuse and insulation development has been prepared and copies have been submitted to the AEC and NAVFAC for review. 


\subsection{FULL-SCALE FUSIBLE INSULATION EVALUATION TEST}

The assembly of the system was completed and operation with the 12 heat pipes was started the first week in March. A full power run under essentially normal design conditions was made and the data were recorded. The mean vapor temperature of the heat pipes was approximately $930^{\circ} \mathrm{F}$. The maximum screen and heater surface temperatures measured were approximately $1100^{\circ} \mathrm{F}$ and $1500^{\circ} \mathrm{F}$, respectively. The heat block-shield was not isothermal from top to bottom; there was a temperature drop of about $100^{\circ} \mathrm{F}$ in the top $10 \mathrm{in}$. from the approximately constant $1100^{\circ} \mathrm{F}$ that existed over the heated length in the heat pipe bolt circle.

The $930^{\circ} \mathrm{F}$ mean vapor temperature of the heat pipes is about $125^{\circ} \mathrm{F}$ lower than was expected based upon the results of the pre-testing of three of the heat pipes. It is believed that the lower temperature resulted from the heat dump being more effective than the calculations had indicated because of eccentricity of the heat pipes in the water-cooled sleeves. The length of the cooling coil for the heat dump on each heat pipe will be shortened approximately $17 \%$ to reduce the effective area of the heat sink. This should result in a vapor temperature of approximately $1030^{\circ} \mathrm{F}$. This modification should be completed early in April.

\subsection{FUEL CAPSULE TESTS}

The Isotope Kilowatt Program test fuel capsules, shown prior to loading in Fig. 1, were completed and received an initial dimensional inspection. The capsules then received the preconditioning heat treatment at $1600^{\circ} \mathrm{F}$ for I hr in an argon atmosphere and were allowed to air cool. Figures 2, 3, and 4 show capsule No. 2 following the heat treatment. Capsule No. I was then shipped to the Naval Ship Research and Development Center, Bethesda, Maryland, for hydrostatic testing.

Capsule No. 2 was submitted to a program of five tests. Prior to each test and following each test, the capsule was leak tested, dimensionally inspected, and photographed. 


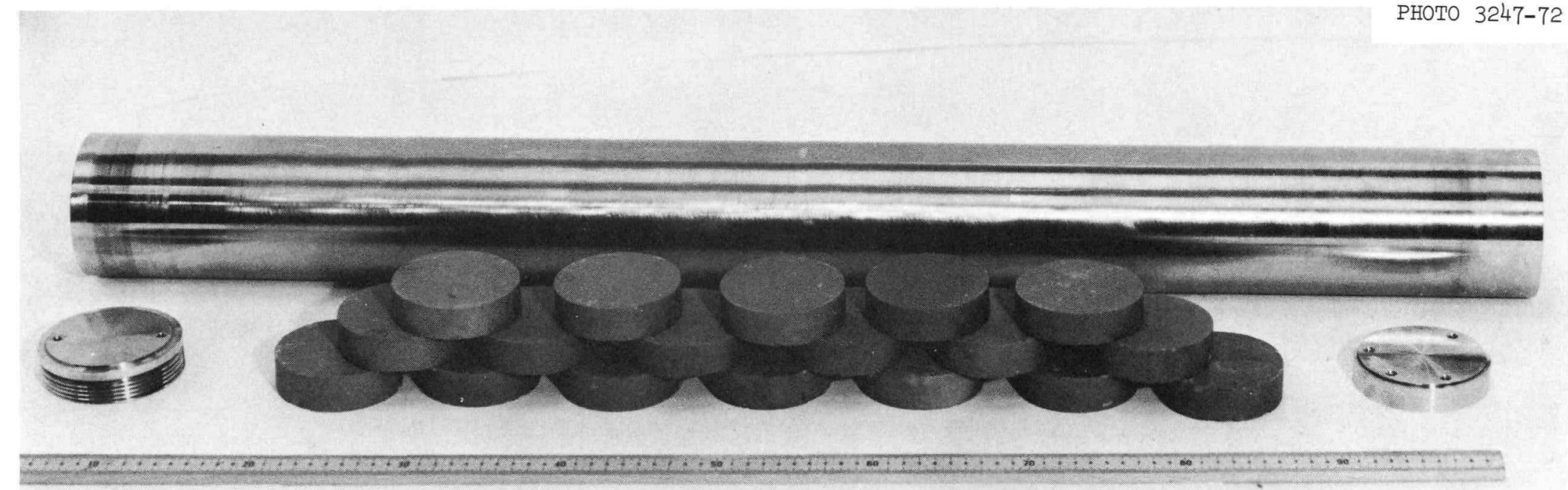

Fig. 1. IKP capsule and inert $\mathrm{SrTiO}_{3}$ pellets prior to assembly. 


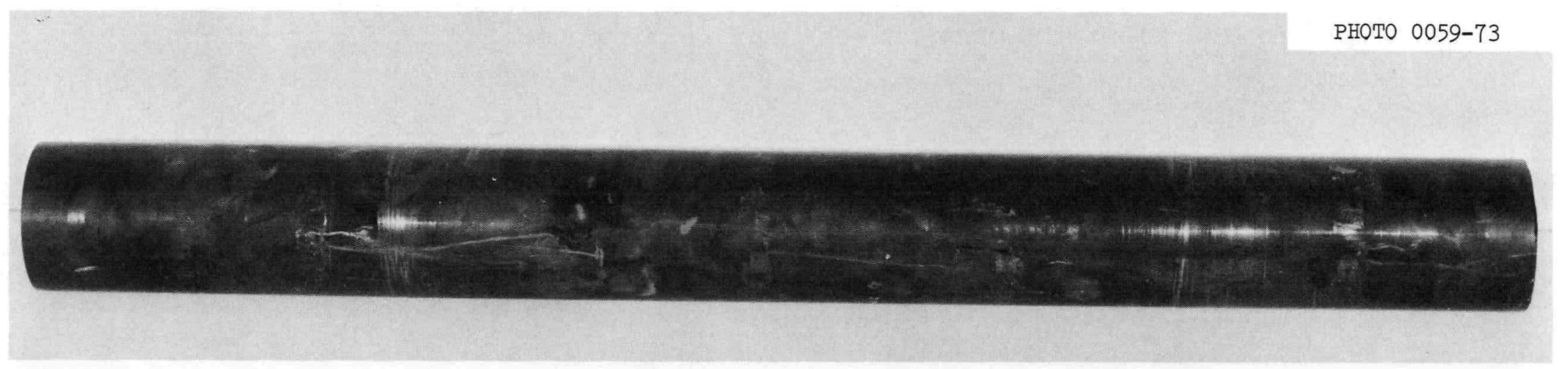

Fig. 2. IKP capsule No. 2 side view after initial heat treatment. 


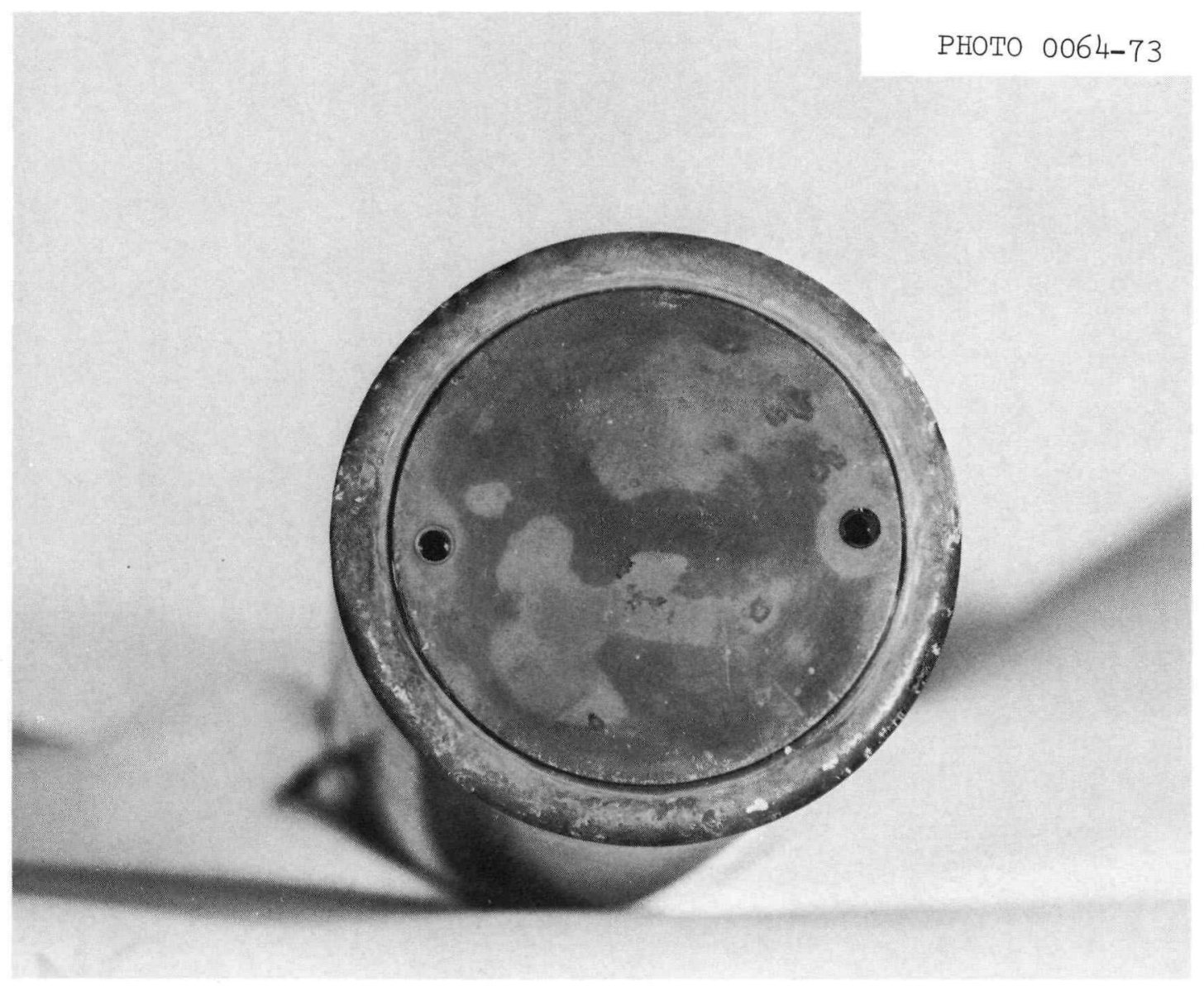

Fig. 3. IKP capsule No. 2 top end view after initial heat treatment. 


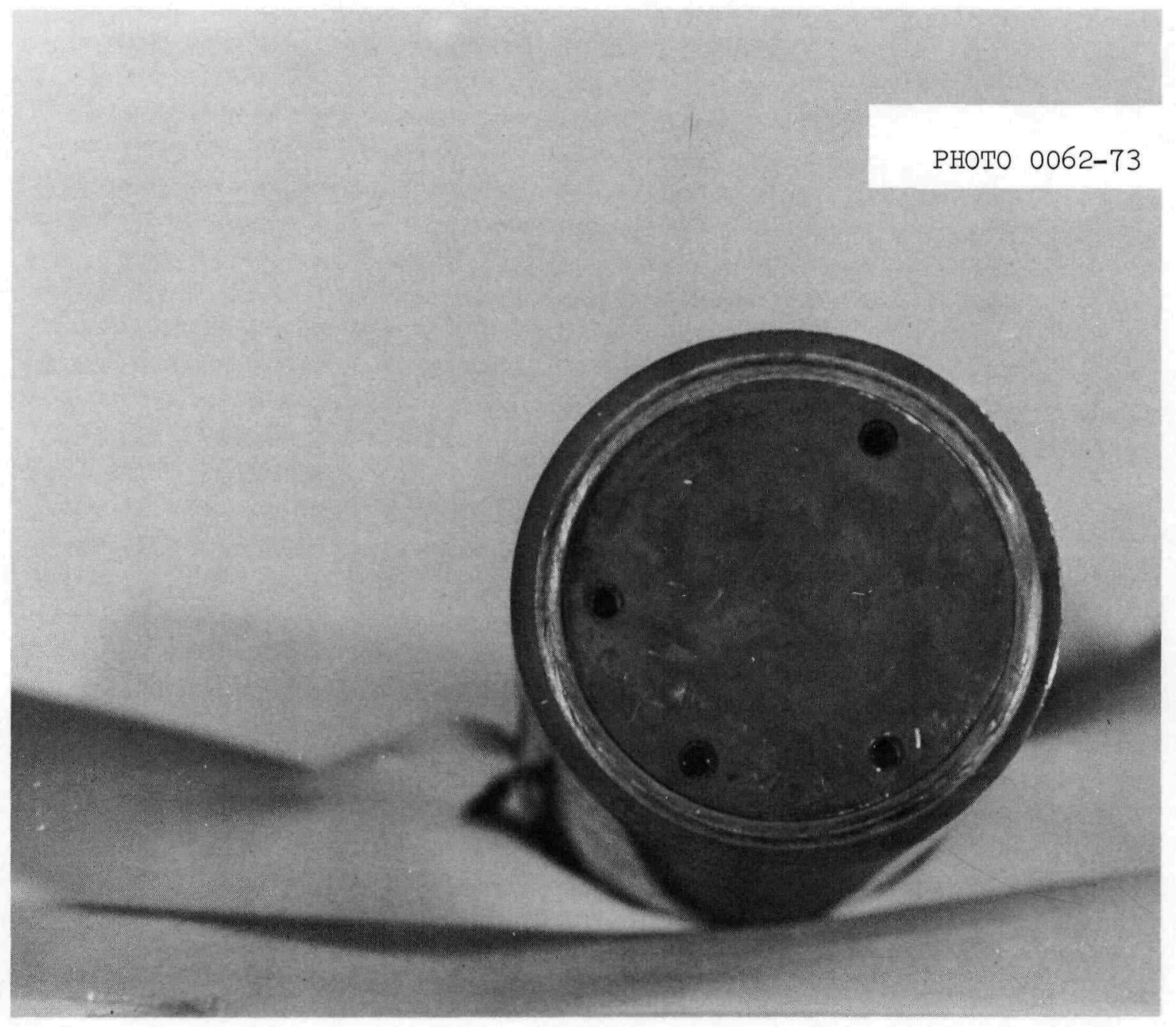

Fig. 4. IKP capsule No. 2 bottom end view after initial heat treatment. 
Test 2-1 was a heating test which consisted of heating the capsule in a tube furnace in an air atmosphere to $800^{\circ} \mathrm{C}$ for $30 \mathrm{~min}$. The clam shell furnace was opened and the capsule and furnace allowed to air cool. There was no detectable change in the capsule.

Test 2-2 was a thermal shock test which consisted of heating the capsule to $800^{\circ} \mathrm{C}$ and then plunging the capsule into a $450-$ gal water bath cooled to $1 / 2^{\circ} \mathrm{C}$ with ice. The stirred bath increased in temperature to $2^{\circ} \mathrm{C}$ after 25 min. There was no change in the capsule.

Test 2-3 was an impact test of the capsule upon the plasma arc-welded top-end edge. The capsule was heated to $855^{\circ} \mathrm{C}$ in the tube furnace, which was mounted vertically on top of a 40 -ft steel drop tower. The capsule was lowered into a cradle to hold the capsule to an $8 \mathrm{deg}$ angle with the vertical. This placed the center of gravity of the capsule directly over the edge of the capsule. The capsule and cradle were released within 29 sec of the start of the removal of the capsule from the furnace. The capsule and cradle free-dropped down the guide rail for $29 \mathrm{ft} 7 \mathrm{in} .(9.02 \mathrm{~m})$ and impacted upon a steel pad set into a concrete base. The 29-ft 7-in. drop height meets the IAEA Safety Series No. 33 specification for $9 \mathrm{~m}$, but was $5 \mathrm{in}$. short of the $30 \mathrm{ft}$ that was specified in the test procedure. This lessened drop height was inadvertently caused by a last minute change from a mechanical to a longer hydraulic release mechanism. The temperature of the capsule at impact was estimated to be $979^{\circ} \mathrm{C}$ on the outer surface and $820^{\circ} \mathrm{C} \mathrm{I} / 8 \mathrm{in}$. below the surface, using the air cool-down temperature curves. The curves, Fig. 5, were obtained by heating and air cooling a 110-1b steel test piece with one thermocouple spot-welded to the outer skin and another inserted into a hole drilled l-in. deep into the end $1 / 8 \mathrm{in}$. from the outer surface. The top end of the capsule was deformed with a $0.115 \mathrm{in}$. bulge in the wall threaded area and the end was deflected $7 / 32 \mathrm{in}$. from perpendicular with the axis of the capsule. A photograph of the top end after impact is shown in Fig. 6. A hair-line crack approximately 2 in. long was detected in the cap seal weld within the impact print area. The crack is shown clearer by dye penetrant exposure in Fig. 7. The crack showed a gross leak indication upon leak testing. No high-speed film of the impact was obtained due to the failure of the camera to operate. Figure 8 is a sketch of the top end deformation. 


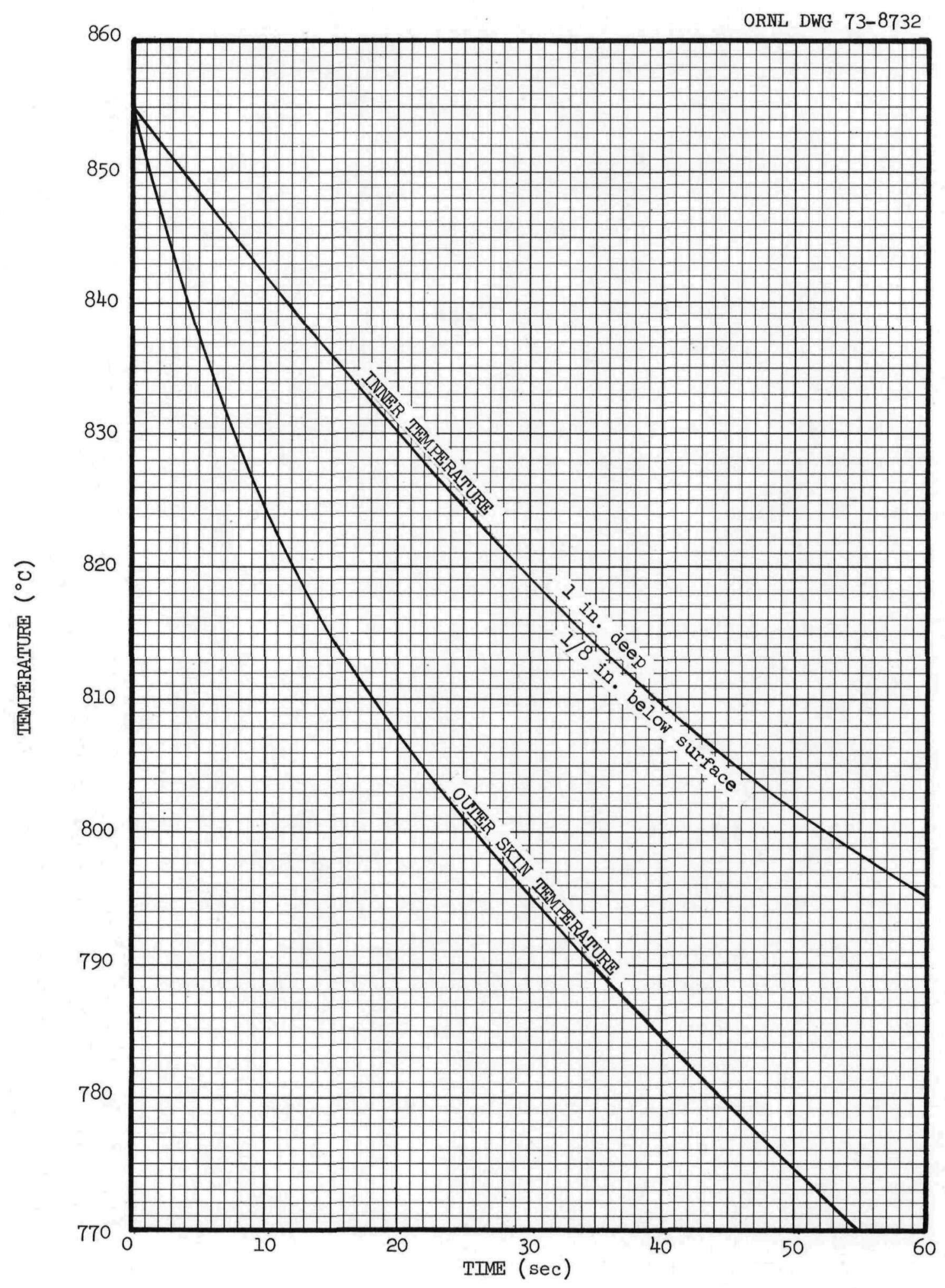

Fig. 5. Air cool-down temperatures for steel test piece. 
РНОTO 0205-73

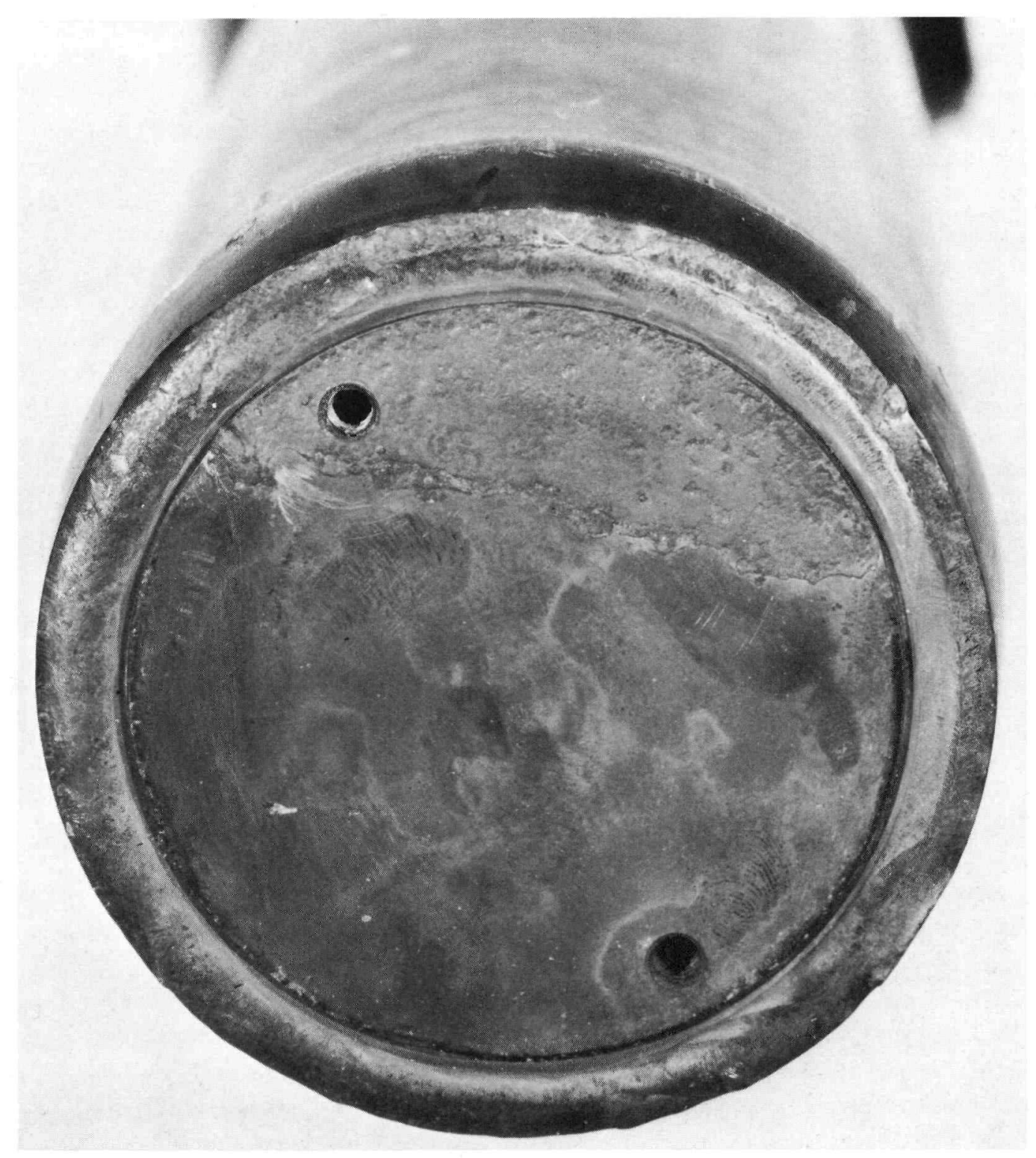

Fig. 6. IKP capsule No. 2 top end view after 30-ft drop test onto top end. 


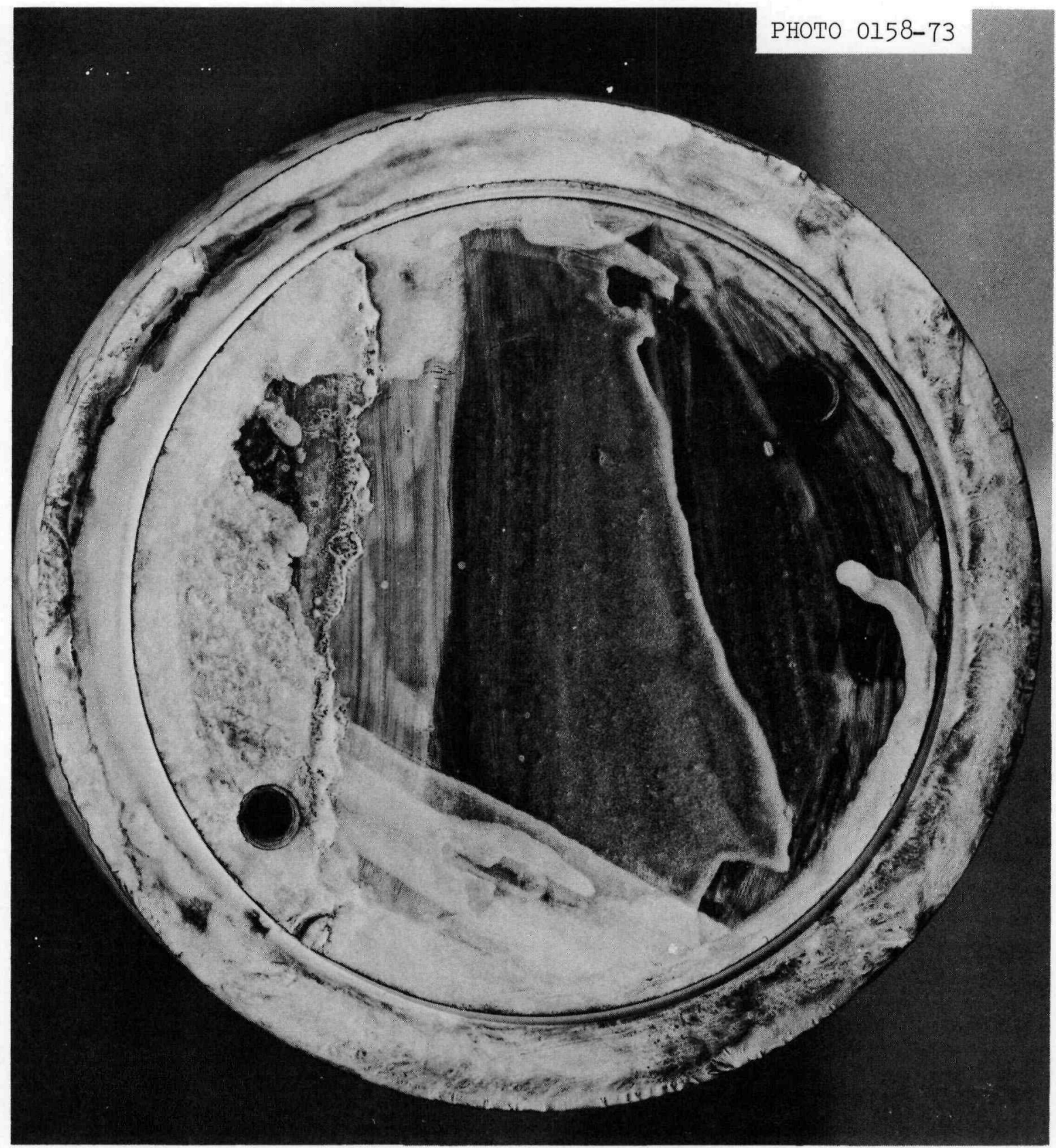

Fig. 7. IKP capsule No. 2 top end view - dye penetrant exposure of crack in weld after 30-ft drop test onto top end. 


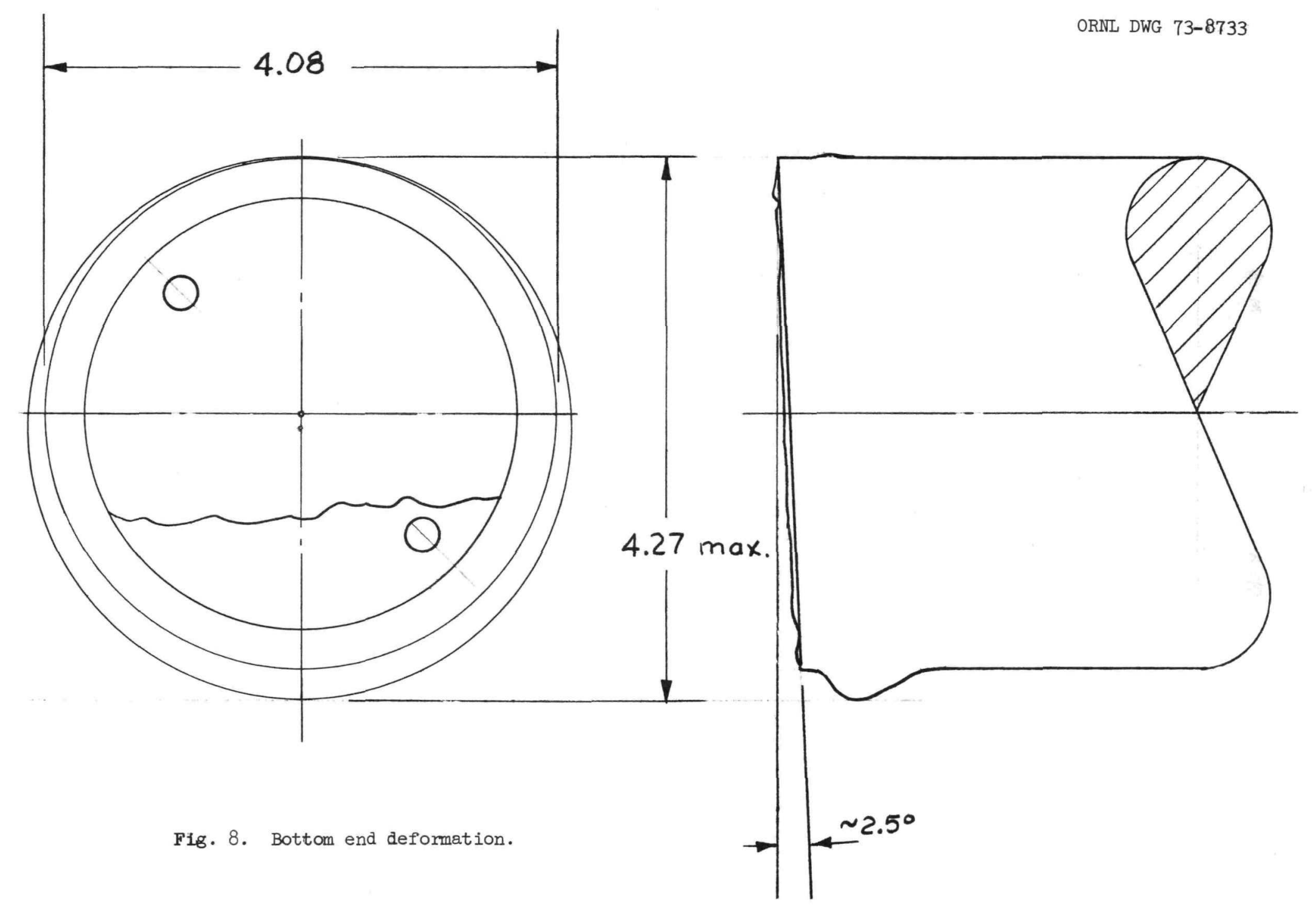

Fig. 8. Bottom end deformation. 
Test 2-4 was an impact test of the capsule upon the electron-beam welded bottom end edge. The capsule was heated to $844^{\circ} \mathrm{C}$, lowered into the drop cradle and released within $36 \mathrm{sec}$ of the start of removal from the furnace. The estimated impact temperature from test cooling curves was $786^{\circ} \mathrm{C}$ on the capsule surface and $805^{\circ} \mathrm{C} 1 / 8$ in. below the capsule surface. The impact caused an 0.050-in. bulge in the capsule wall near the inner end of the cap and the end was deflected 3/16 in. from the perpendicular with the capsule axis. Figure 9 shows the bottom end impact area, and Fig. 10 shows the top end (on the left) and bottom end deformation and side bulging. The top end crack was sealed with Glyptol, and the capsule was leak tested. No leaks were found.

The high-speed film (2000 frames/sec) of the bottom end impact showed an impact velocity of $42.6 \pm 1.3 \mathrm{ft} / \mathrm{sec}$. A free drop velocity for $29 \mathrm{ft}$ $7 \mathrm{in}$. is $43.6 \mathrm{ft} / \mathrm{sec}$. The camera speed accuracy is $\pm 3 \%$.

Test 2-5 was a percussion test in which a 1-in. diameter, $15.43 \mathrm{lb}$ (7 kg) steel rod was dropped $40 \mathrm{in.}(1.02 \mathrm{~m}$ ) onto the middle of the capsule. The capsule was heated to $825^{\circ} \mathrm{C}$ and quickly placed onto a $1 / 16$ in.-thick sheet of steel which covered a sheet of $1 / 4-i n$. lead. The rod was dropped through a guide tube placed on the midale of the capsule. No change in the capsule was detected. 
PHOTO $0207-73$

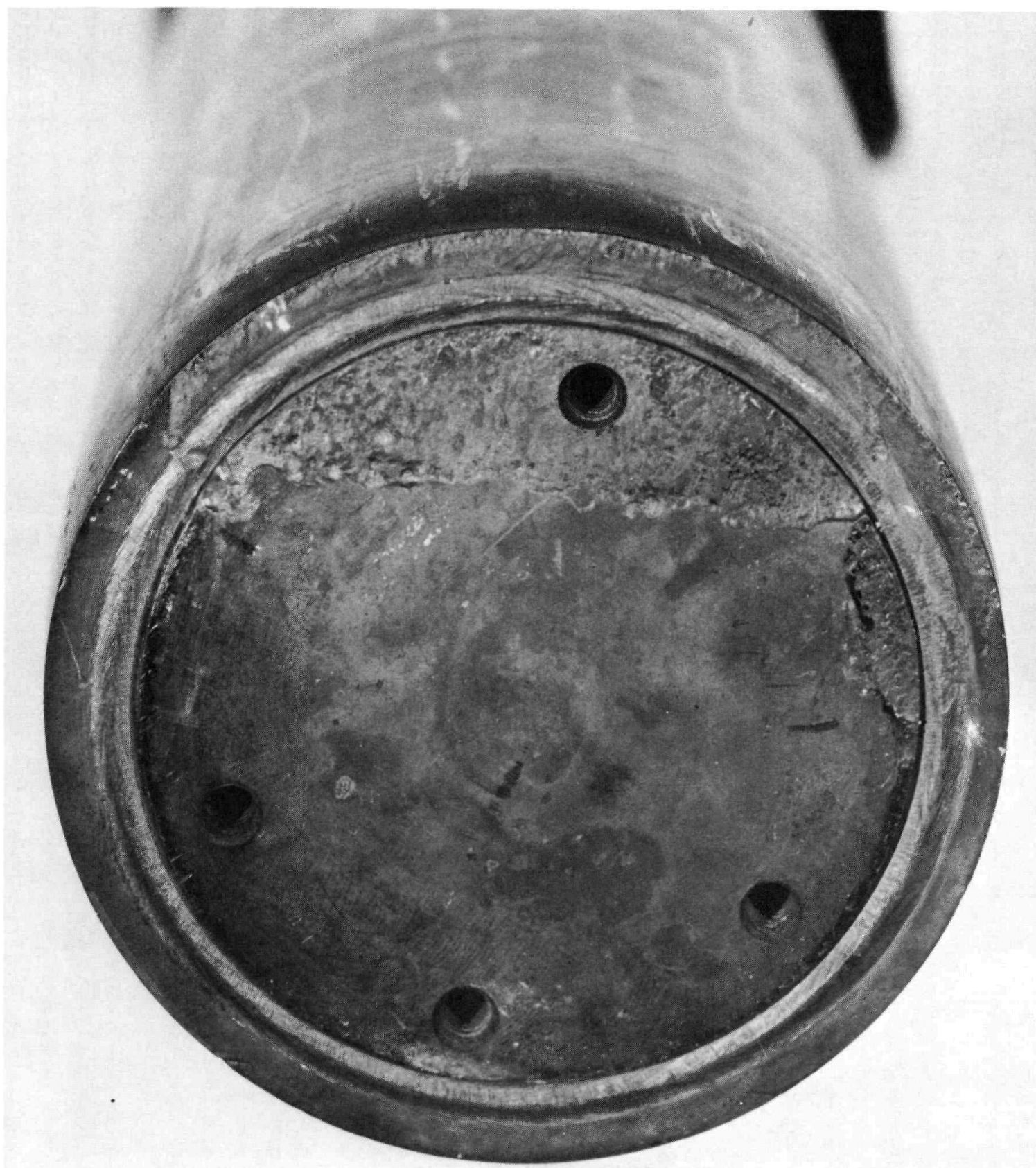

Fig. 9. IKP capsule No. 2 bottom end view after 30-ft drop test onto bottom end. 


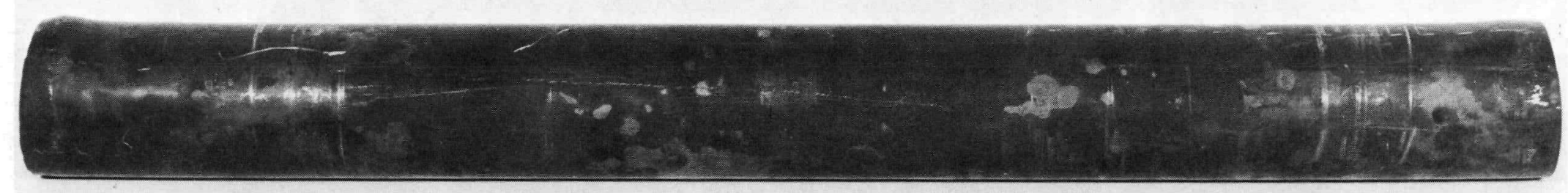

Fig. 10. IKP capsule No. 2 side view after 30-ft drop test onto bottom end.

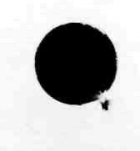




\section{REFERENCES}

1. R. A. Robinson, Isotope Kilowatt Program Task I - Conceptual Design and Evaluation, USAEC Report ORNL-TM-2366, Oak Ridge National Laboratory, January 1970.

2. A. P. Fraas, Program Director, Isotope Kilowatt Program Quarterly Progress Report for Period Ending March 31, 1970, USAEC Report ORNLTM-3011, Oak Ridge National Laboratory, July 1970.

3. A. P. Fraas, Program Director, Isotope Kilowatt Program Quarterly Progress Report for Period Ending June 30, 1970, USAEC Report ORNLTM-3099, Oak Ridge National Laboratory, September 1970.

4. A. P. Fraas, Program Director, Isotope Kilowatt Program Quarterly Progress Report for Period Ending September 30, 1970, USAEC Report ORNL-TM-3214, Oak Ridge National Laboratory, December 1970.

5. A. P. Fraas, Program Director, Isotope Kilowatt Program Quarterly Progress Report for Period Ending December 31, 1970, USAEC Report ORNL-TM-3292, Oak Ridge National Laboratory, February 1971.

6. A. P. Fraas, Program Director, Isotope Kilowatt Program Quarterly Progress Report for Period Ending March 31, 1971, USAEC Report ORNLTM-3394, Oak Ridge National Laboratory, May 1971.

7. A. P. Fraas, Program Director, Isotope Kilowatt Program Quarterly Progress Report for Period Ending June 30, 1971, USAEC Report ORNLTM-3491, Oak Ridge National Laboratory, August 1971.

8. A. P. Fraas and G. Samuels, Isotope Kilowatt Program Quarterly Progress Report for Period Ending September 30, 1971, USAEC Report ORNL-TM-3592, Oak Ridge National Laboratory, November 1971.

9. A. P. Fraas and G. Samuels, Isotope Kilowatt Program Quarterly Progress Report for Period Ending December 30, 1971, USAEC Report ORNL-TM-3687, Oak Ridge National Laboratory, April 1972.

10. A. P. Fraas and G. Samuels, Isotope Kilowatt Program Quarterly Progress Report for Period Ending March 31, 1972, USAEC Report ORNLTM-3805, Oak Ridge National Laboratory, June 1972.

11. A. P. Fraas and G. Samuels, Isotope Kilowatt Program Quarterly Progress Report for Period Ending June 30, 1972, USAEC Report ORNLTM-3922, Oak Ridge National Laboratory, August 1972.

12. A. P. Fraas and G. Samuels, Isotope Kilowatt Program Quarterly Progress Report for Period Ending September 30, 1972, USAEC Report ORNL-TM-4009, February 1973.

13. A. P. Fraas and G. Samuels, Isotope Kilowatt Program Quarterly Progress Report for Period Ending December 31, 1972, USAEC Report ORNL-TM-4129, Oak Ridge National Laboratory, to be published. 
Blank Page 
ORNL TM 4243

Internal Distribution

$\begin{array}{ll}\text { 1. } & \text { S. E. Beall } \\ \text { 2. T. A. Butler } \\ \text { 3. W. B. Cottrell } \\ \text { 4. W. C. Cox } \\ \text { 5. F. L. Culler } \\ \text { 6. R. G. Donnelly } \\ \text { 7-16. A. P. Fraas } \\ \text { 17. J. H. Frye, Jr. } \\ \text { 18. J. H. Gillette } \\ \text { 19. A. G. Grindell } \\ \text { 20. K. W. Haff } \\ \text { 21. H. W. Hoffman } \\ \text { 22. R. S. Holcomb } \\ \text { 23. P. R. Kasten } \\ \text { 24. M. E. Lackey } \\ \text { 25. E. Lamb } \\ \text { 26. D. B. Lloyd } \\ \text { 27. M. I. Lundin } \\ \text { 28. R. N. Lyon } \\ \text { 29. R. E. MacPherson } \\ \text { 30. H. C. McCurdy } \\ \text { 31. A. J. Miller }\end{array}$

\author{
32. A. M. Perry \\ 33. R.A. Robinson \\ 34. M. W. Rosenthal \\ 35. A. F. Rupp \\ 36-40. G. Samuels \\ 4l. Myrtleen R. Sheldon \\ 42. A. C. Schaffhauser \\ 43. M. J. Skinner \\ 44. A. M. Smith \\ 45. I. Spiewak \\ 46. D. A. Sundberg: \\ 47. D. B. Trauger \\ 48. J. J. Tudor \\ 49. A. M. Weinberg: \\ 50. G. D. Whitman \\ 5l. J. V. Wilson \\ 52. H. C. Young \\ 53. Biology Library \\ 54-55. Central Research Library \\ 56. Y-12 Document Reference Section \\ 57-66. Laboratory Records Department \\ 67. Laboratory Records Department (RC)
}

External Distribution

68. D. F. Cope, RDT Site Office, ORNL

69. W. M. Crim, Jr., Research and Technology Department, Building 322 , Ft. Belvoir, Virginia 22060.

70. R. E. English, NASA, Lewis Research Center, Cleveland, Ohio 44135.

71. E. E. Fowler, Division of Applied Technology, AEC, Washington, D. C., 20545.

72-76. W. D. Holloman, Division of Reactor Development and Technology, AEC, Washington, D. C. 20545.

77-78. M. Klein, Division of Space Nuclear Systems, AEC, Washington, D. C., 20545 .

79. T. A. McLaughlin, Isotopic Auxiliary Power Branch, AEC, Washington, D. C., 20545.

80-84. Nuclear Enginnering Division, Naval Facilities Engineering Command, Washington, D. C. 20545.

85. J. Pidkowicz, RDT Site Office, ORNL.

86. W. B. Taylor, Technical Director, U.S. Army Mobility Equipment Research and Development Center, Ft. Belvoir, Virginia 22060.

87. J. G. Whiteaker, Chief, Auxiliary Projects Branch, Division of Reactor Development and Technology, AEC, Washington, D. C. 20545. 
88-90. Director, Division of Reactor Licensing, USAEC, Washington, D. C. 20545.

91-92. Director, Division of Reactor Standards, USAEC, Washington, D. C., 20545.

93-109. Manager, Technical Information Center, AEC. (For ACRS Distribution)

110. Research and Technical Support Division, AEC, ORO.

111-112. Technical Information Center, AEC. 